\title{
チトクロム $c_{6}$ の結晶構造解析
}

○佐々木智一 - 内田朗 - 大西勲 - 吉崎文則 - 山崎武信 - 加藤栄

(東邦大理)

紅藻スサビノリ（Porphyra Yezoensis) のチトクロム $c_{6}$ は、 1 分子あたり 1 つのへムcを含む 分子量9,7000タンパク質で、光 合成系において、チトクロム $b_{6} f$ 複合体からチトクロムP700への 電子伝達を行う。同様の働きをす るタンパク質としてはプラストシ アニンが知られているが、両タン パク間のアミノ酸配列と立体構造 は全く異なっている。種により、 両方とも発現しうるもの、片方の みを持つものがある。本研究でX 線結晶構造解析を行っているスサ

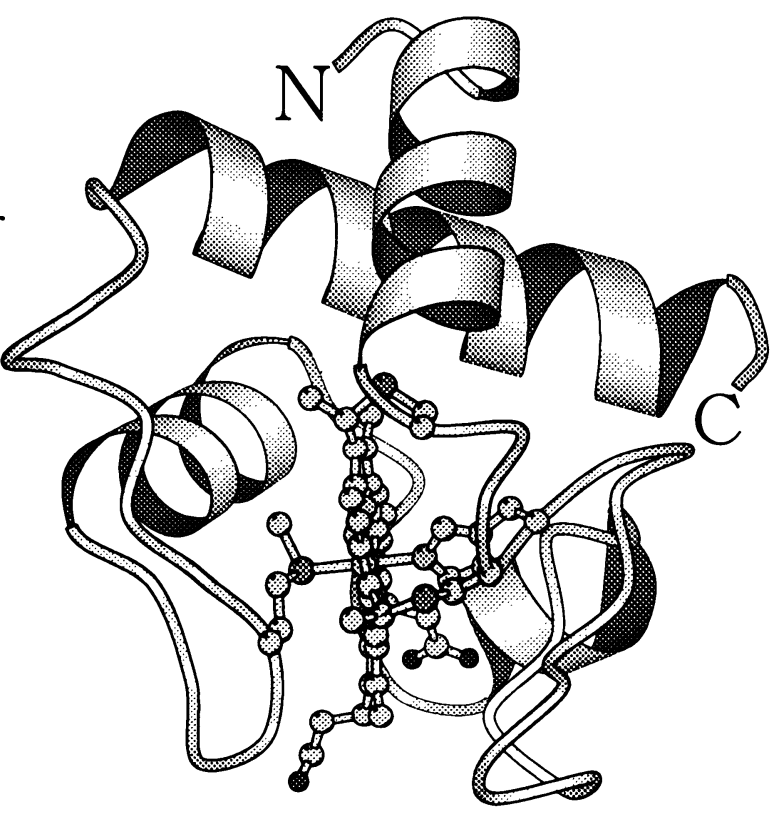
ビノリはチトクロム $c_{6}$ のみを持つ。

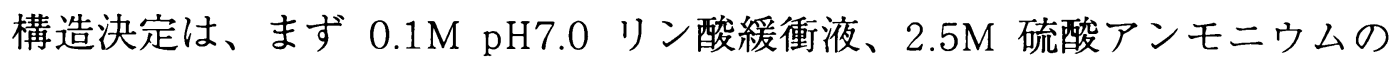
条件で結晶化して得られた正方両錘形結晶のデータを、298KでRーAXIS II C で測定し、Chramydomonas reinhardtiiのチトクロム $c_{6}$ の構造を用いた分子 置換法により初期位相を決定した。その後結晶化条件を再検討し、0.1M $\mathrm{pH} 4.0$ クエン酸緩衝液、1.5M 硫酸アンモニウムの条件で結晶化した結晶を $100 \mathrm{~K}$ でRーAXIS II Cで測定し、分解能 $1.8 \AA$ A でのデー夕を得た。

得られた立体構造にはN末端およびC末端にそれぞれ $11 、 17$ 残基から なる長いヘリックスが存在し、両者はほぼ直交している。他に $7 、 10$ 残基 の 2 つのリックスが存在する。2つのCys残基がへムの側鎖と共有結合し、 His とMet残基が第 5 、第 6 配位子として鉄原子に結合している。これは他藻 類のチトクロム $c_{6}$ と共通の構造である。スサビノリチトクロム $c_{6}$ の残基数は 85 残基で、構造が報告されている他のチトクロム $c_{6}$ に比べて短い。 2 残基 のデリーションが、タンパク表面に露出しているへムのプロピオン酸近くに 存在するループ部分に見られる。 